İSKEMIK İNME TANISI:

TÜRK BEYIN DAMAR HASTALIKLARI DERNEĞİ İNME TANI VE TEDAVİ KILAVUZU - 2015

\author{
Ethem Murat ARSAVA', Vesile ÖZTÜRK², Kürşad KUTLUK², Nevzat UZUNER ${ }^{3}$ \\ ${ }^{1}$ Hacettepe Üniversitesi Tıp Fakültesi, Nöroloji Anabilim Dalı, ANKARA \\ ${ }^{2}$ Dokuz Eylül Üniversitesi Tıp Fakültesi, Nöroloji Anabilim Dalı, İZMiR \\ ${ }^{3}$ Eskişehir Osmangazi Üniversitesi Tıp Fakültesi, Nöroloji Anabilim Dalı, ESKișEHİR
}

ÖZET

İskemik inme ve geçici iskemik atak kavramları ile iskemik inmede klinik tanı, uygulanacak laboratuvar ve radyolojik incelemelerden kısaca söz edilecektir. Bunların yanı sıra, iskemik inmede nedene yönelik tanımlamalar hakkında bilgi verilecektir.

Anahtar Sözcükler: İskemik inme, geçici iskemik atak, klinik tanı.

\title{
DIAGNOSIS OF ISCHEMIC STROKE: \\ GUIDELINES OF TURKISH SOCIETY OF CEREBROVASCULAR DISEASES - 2015
}

\begin{abstract}
The concepts of ischemic stroke and transient ischemic attack as well as clinical diagnosis, applicable laboratory and radiolojical examinations for ischemic stroke will be briefly mentioned. Also, an information about cause-specific definitions in ischemic stroke will be offered.

Key Words: Ischemic stroke, transient ischemic attack, clinical diagnosis.
\end{abstract}

\footnotetext{
Yazışma Adresi: Prof. Dr. Nevzat Uzuner Eskişehir Osmangazi Üniversitesi Tıp Fakültesi Nöroloji Anabilim Dalı, Eskişehir.

E-mail: nevzatuzuner@gmail.com Telefon: 0222 2392979/3650

Bu makale şu şekilde atıf edilmelidir: Arsava E. M, Öztürk V, Kutluk K, Uzuner N. İskemik İnme Tanısı: Türk Beyin Damar Hastalıkları Derneği İnme Tanı ve Tedavi Kılavuzu - 2015. Türk Beyin Damar Hastalıkları Dergisi 2015; 21(2): 80-84 doi: 10.5505/tbdhd.2015.77486.
} 


\section{GİRiş}

\section{İskemik İnme Tanısı ve Sınıflama}

İnme ve geçici iskemik atak (GİA) tanımları, önceleri semptom ve bulguların süresine göre belirleniyordu. Klinik gözlem ve modern görüntüleme yöntemleriyle gerçekleștirilen güncel araştırmalar, beyin iskemisinin süresinin ve geri dönebilirliğinin değişken olduğunu göstermektedir. ${ }^{1}$

Modern görüntüleme yöntemleri, günümüzde infarktlı beyin dokusuyla, perfüzyonu bozulmuş ancak henüz geri dönüşsüz hasar görmemiş dokuyu ayırt etmeyi hedeflemektedir. Sürenin değişken oluşu nedeniyle, inme ile GİA'yı ayrıștırmak için sabit bir süre kıstası olmaması gerektiği kanısı bulunmaktadır. ${ }^{1}$

'Geçici' kelimesi, semptomların kalıcl olmadığını gösterir. Modern görüntüleme ile, klinik olarak geçici beyin iskemisi semptom ve bulgularına sahip olmalarına rağmen, beyin infarktı olan çok sayıda hasta görülmektedir. İskemi eğer doku nekrozuna sebep oluyorsa, iskemiyi geçici olarak tanımlamak doğru değildir. Benzer şekilde, iskemi sonucu uzun süren bulgular ortaya çlkabilir (ve durumu inme olarak tanımlayabilir), ancak kalıcı bir infarkt gelişmemiş olabilir. ${ }^{1}$

İskemik inmenin kapsamlı bir tanımı, iskemi sürecini doğru bir şekilde belirleyebilmek için klinik semptomlar ve infarkt kanıtları gerektirir. ${ }^{1}$

İskemik inme şüphesi olan hastalarda, bazı testler hızlı bir şekilde rutin olarak gerçekleştirilmelidir. Bunun temel amacl, önemli olabilecek alternatif tanıları dışlamak, eşlik eden ciddi durumları tespit etmek, tedavi seçimini desteklemek ve inmenin akut tıbbi ve nörolojik komplikasyonlarını belirlemektir. ${ }^{1,2}$

\section{Serebrovasküler olay için önerilen tanı akışı ${ }^{1}$}

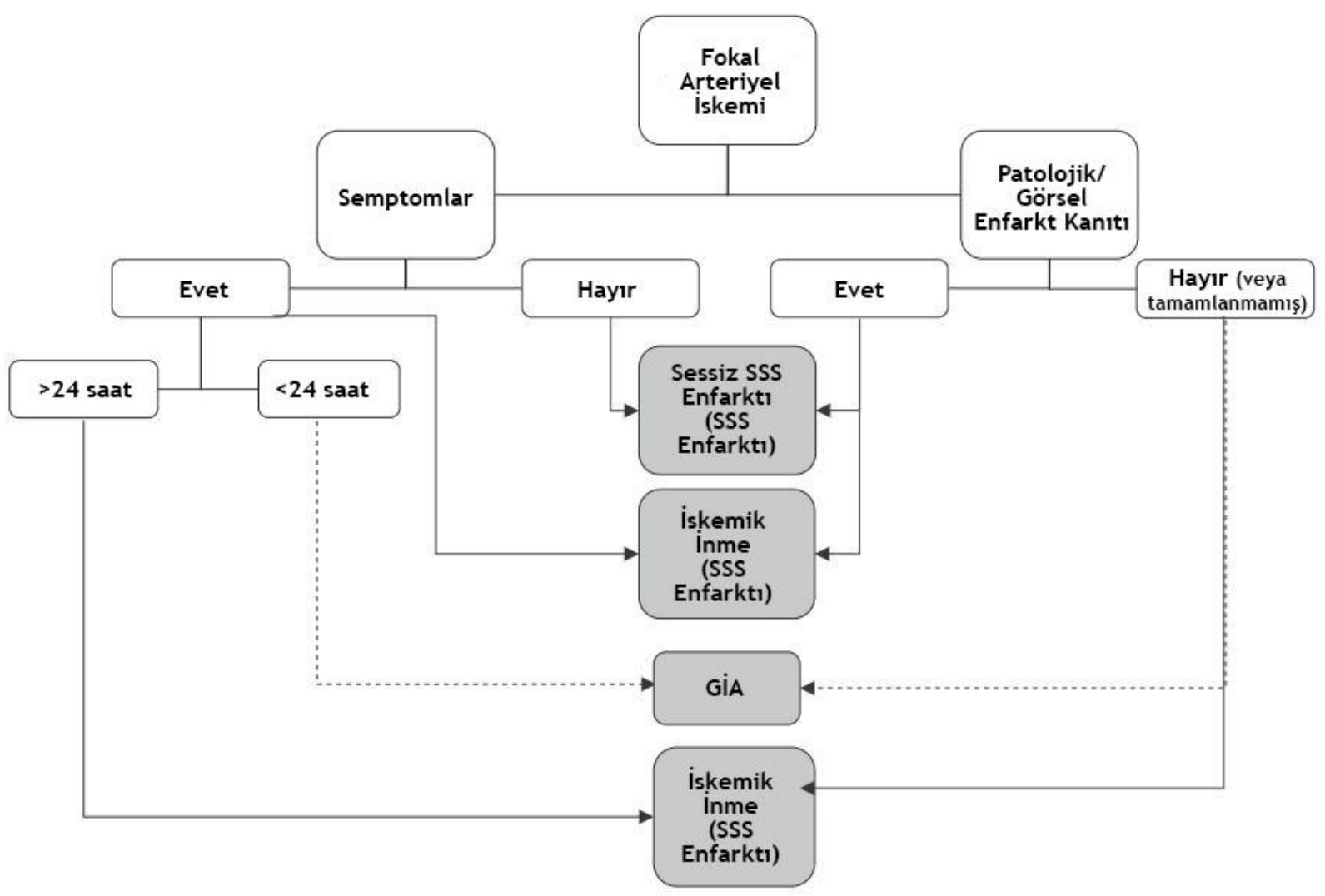


Iskemik inme, fokal serebral, spinal veya retinal infarkt sonucu gelișen nörolojik disfonksiyon vakasıdır. ${ }^{1}$

Geçici iskemik atak, semptomları geçici olan (<24 saat) fokal arteriyel iskemi ve patoloji veya görüntülemede infarkt kanıtı olmayan durumlardır. ${ }^{1}$

Sessiz infarkt ise, görüntüleme veya nöropatolojik olarak MSS infarktı kanıtı olmasına rağmen, bu lezyona bağlı oluşan bir akut nörolojik disfonksiyon hikayesinin olmadığı durumlardır. ${ }^{1}$

\section{Klinik Tanı}

İnme ve GİA'nın klinik tanısı için, iyi bir nöroanatomi ve vasküler anatomi bilgisi gereklidir. İnmenin vasküler bir nedenle oluştuğunu ve hangi damarların dahil olduğunu tespit edebilmek için, sürecin beynin neresinde olduğunu göz önünde bulundurmak gerekir. ${ }^{1}$

İnme mekanizmaları arasında ayırıcı tanıya gitmeden önce, hekimlerin ilk olarak belirtilerin beyin tümörü, metabolik bozukluk, enfeksiyon, demiyelinasyon, intoksikasyon veya travmatik hasar gibi vasküler olmayan bir nedene bağlı olup olmadığını araștırmaları gerekir. ${ }^{1}$

Anamnez ve sistemik hastalıklar hakkında elde edilen bilgiler, patofizyoloji hakkında bilgi verirken, nörolojik muayene hastalık sürecinin yeri hakkında bilgi verir. İnme tanısı, sıklıkla nörolojik bulgulardan elde edilen bilgi ve nörolojik görüntülemeden sağlanan bulguların bir araya getirilmesiyle konur. ${ }^{1}$

İnme mekanizmasının belirlenmesi için, hastanın özgeçmişi ve soygeçmişi, geçmişte yaşanmış inme ve/veya GİA varlığı ve niteliği, inme başlangıcı sırasındaki aktivite, fokal semptom ve bulguların seyri, baş ağrısı ve kusma gibi eşlik eden semptomlar ve bilinç kaybı gibi klinik bilgilerin değerlendirilmesi gerekir. ${ }^{1}$

Fizik muayene, inme mekanizmasının belirlenmesi için ek veri sağlar. Artmıș kan basıncı, kardiyomegali veya üfürüm gibi bulgular bu aşamada yardımcı olabilir. ${ }^{1}$

\section{Radyografik Tanı}

İnme tanısının doğrulanması, ağırlıklı olarak görüntülemeye bağlıdır. BT, beyin tümörü ve subdural hematom gibi inme ile karışabilecek durumların dışlanmasını ve beyin iskemisinin hemorajiden ayırt edilmesini sağlar. BT veya MRG ile yapılan beyin görüntülemesi, infarkt veya hemoraji alanlarını tespit edebilir. ${ }^{1}$

Vasküler hasar bölgelerini besleyen damarlara odaklanarak yapılan servikal ve intrakraniyal arter ve venlerin görüntülemesi, oklüzyon ve malformasyon ve anevrizmaları tespit edebilir. Vasküler görüntüleme USG, BT, MRG veya kateter anjiyografi ile yapılabilir. ${ }^{1}$

Günümüzde, kalıcı doku hasarı ve penumbra olarak bilinen risk altındaki dokunun hızlı bir şekilde belirlenmesi için MRG'nin çok sekanslı kullanımı ön plandadır. Multimodal MRA, DAG, FLAIR ve perfüzyon ağırlıklı MRG, potansiyel olarak geri dönüșlü hasarı gösteren 'uyumsuzluğu' belirlemede kullanılır. Bu görüntüleme yöntemleri, kan akımının normale dönmemesi durumunda, penumbrada kalıcı hasar gelișeceği ve klinik olarak olumsuz sonuçlara yol açacağı fikrine dayanmaktadır.

Doku hacimlerinin uyumsuzluğu, iskemik penumbranın belirlenmesinde radyografik bir indeks olarak kullanılmaktadır. İdeal şartlarda radyografik değerlendirme, daha az oranda geri dönüşsüz olarak infarktlı dokuya ve daha fazla oranda kurtarılabilir penumbraya sahip hastaların belirlenmesini sağlar. ${ }^{1}$

\section{Serum Biyobelirteçleri}

Beyin infarktında biyobelirteçlerin kullanımı, yaygın kullanıma girmemiștir. Sıklıkla kullanılan belirteçler arasında S100 kalsiyum bağlayıcı protein B (S100B), glial fibriler asidik protein, beyin natriüretik peptid ve matriks metalloproteinaz-9 bulunmaktadır; ancak bu testlerin hiçbirisi, hastane laboratuvarları tarafından akut dönemde karar verilmesini sağlayacak bir hızda rutin olarak ölçülmemektedir ve yalnızca klinik araştırmaların ilgi alanındadır. ${ }^{1}$

\section{Öneriler}

1. İnme hastalarının acil değerlendirmeleri için önceden düzenlenmiş bir protokol önerilir. Amaç, hastanın acil servise gelişi sonrası 60 dakika içerisinde değerlendirmenin tamamlanması ve fibrinolitik tedaviye başlanmasıdır.

2. İnme skalası, tercihen NIHSS, kullanımı önerilir.

3. Acildeki ilk değerlendirme sırasında sınırlı sayıda hematolojik, koagülasyon ve biyokimyasal testler önerilir; rtPA öncesinde yalnızca kan glukozu ölçümü gereklidir.

4. Akut iskemik inme ile gelen hastalarda EKG 
değerlendirmesi önerilir ancak IV rtPA başlanmasını geciktirmemelidir.

5. Akut iskemik inme ile gelen hastalarda troponin ölçümü önerilir ancak IV rtPA başlanmasını geciktirmemelidir.

6. Semptomları Devam Eden Akut İnme Hastalarında:

a. Akut iskemik inme tedavisine başlanmadan önce acil serebral görüntüleme önerilir. Çoğu durumda kontrastsız BT, acil müdahale öncesinde gerekli bilgiyi sağlayacaktır.

b. IV rtPA uygulamasından önce kontrastsız BT veya MRG'den birisi önerilir.

c. BT'de erken iskemik değişikliklerin varlığında, yaygınlığına bakılmaksızın IV fibrinolitik tedavi önerilir.

d. İntra-arteriyel fibrinoliz veya mekanik trombektomi yapılması düşünülüyorsa, görüntüleme sırasında non-invazif intrakraniyal vasküler görüntüleme önerilir; ancak gerekli olduğu durumlarda IV rtPA tedavisini geciktirmemelidir.

e. IV fibrinoliz için uygun hastalarda, kraniyal görüntüleme çalışması, hastanın acil servise gelişinden sonraki 45 dakika içerisinde, BT ve MRG görüntülerinde beyin parenkimini değerlendirme konusunda tecrübeli bir hekim tarafindan yorumlanmalıdır.

f. Perfüzyon BT ve perfüzyon ve diffüzyon MRG görüntülemesi, IV fibrinoliz için uygun zamanı geçirmiş olan hastalarda akut reperfüzyon tedavisine karar verilmesi için düşünülebilir.

g. Kontrastsız BT'de belirgin hipodansite varlığl, fibrinoliz alan hastalarda hemoraji riskini artırabilir. Belirgin hipodansite, MCA alanının üçte birinden fazlasını ilgilendiriyorsa, IV rtPA yapılmamalıdır.

7. Semptomları Düzelmiș Olan Akut İnme Hastalarında:

a. GİA şüphesi olan hastalarda, servikal vasküler yapının non-invazif görüntülemesi rutin olarak yapılmalıdır.

b. Geçici nörolojik belirtileri olan hastalarda, semptom başlangıcından sonraki 24 saat içerisinde veya başvuruda geciken hastalarda en kısa sürede nörogörüntüleme yapılmalıdır. DAG dahil MRG, tercih edilen görüntüleme yöntemi olmalıdır.

\section{Etiyolojik Tanı}

İskemik inmenin etiyolojisi, prognoz, sonuçlar ve hasta yönetimini etkileyen bir unsurdur. İnme alt tiplerinin hassas analizi, klinik özellikler, tanısal testler ve potansiyel etiyolojik faktörler hakkında bilgi toplanmasını gerektirir. ${ }^{3}$

Nedene yönelik olarak en yaygın kullanılan sistem, TOAST sinıflamasıdır. ${ }^{4}$ TOAST sinıflaması, Akut İnme Tedavisinde Org 10172 Çalışması (Trial of Org 10172 in Acute Stroke Treatment) için geliştirilen ve etiyolojiyi esas alan bir iskemik inme alt tip kategorizasyon sistemidir. ${ }^{3}$

TOAST sinıflaması 5 kategoriye sahiptir:

1. Büyük arter aterosklerozu

2. Kardiyoembolizm

3. Küçük damar oklüzyonu

4. Bilinen bir başka sebepten kaynaklanan inme

5. Sebebi bilinmeyen inme ${ }^{3}$

Genel olarak, serebral infarkt hastalarının \%20'sinden kardiyak emboli, \%50'sinden büyük damar hastalığı ve \%25'inden ise küçük damar hastalığı sorumludur. Hastaların \%25-39'unda kesin bir sebep belirlenememektedir. ${ }^{5}$

Tanı, klinik özellikler ve beyin görüntülemesi (BT/MRG), kardiyak görüntüleme (ekokardiyografi, vs.), ekstrakraniyal arterlerin dupleks görüntülemesi, arteriyografi ve tromboza yatkınlık gibi durumların laboratuvar incelemeleri gibi testlerden elde edilen bilgilere dayanır. ${ }^{3}$

Büyük arter aterosklerozu: Bu hastalarda; boyun veya beyin damarlarının, olasılıkla ateroskleroza bağlı ciddi (>\%50) stenozu veya oklüzyonuna dair klinik veya görüntüleme bulguları vardır. Klinik bulgular arasında serebral kortikal işlev kaybı (afazi, motor bozukluk, vs.) veya beyin sapı veya serebellar disfonksiyon bulunur. İntermitan kladikasyon, aynı vasküler alanda GİA, karotis üfürümü veya zayıf nabız hikayesi klinik tanıyı destekler. BT veya MRG'de 1,5 cm'in üzerindeki kortikal veya serebellar lezyonların ve beyin sapı veya subkortikal hemisferik infarktların varlığı, potansiyel olarak büyük arter aterosklerozuna bağlıdır. Uygun bir intrakraniyal veya ekstrakraniyal arterin, dupleks görüntüleme veya arteriyografi ile kanıtlanmış \%50'den fazla oranda stenozu gereklidir. Tanısal araştırmalar, potansiyel kardiyak emboli sebeplerini dışlamalıdır. ${ }^{3}$ 
Kardiyak emboli: Bu kategori, kalpte oluşan bir emboliye bağlı olduğu düşünülen arteriyel oklüzyon hastalarını içerir. Olası veya olanaklı bir kardiyak emboli tanısı için, en az bir tane kardiyak emboli kaynağı tespit edilmiş olmalıdır. Klinik ve görüntüleme bulguları, büyük arter aterosklerozunda görülenlere benzerdir. Sistemik emboli veya birden fazla vasküler alanda geçirilmiş GİA veya inme bulgusu, kardiyojenik inme tanısını destekler. Tromboz veya embolinin büyük arter aterosklerozuna bağlı potansiyel sebepleri dışlanmalıdır. ${ }^{3}$

Küçük arter oklüzyonu: $\mathrm{Bu}$ kategori, diğer sinıflandırmalarda laküner infarkt olarak tanımlanan hastaları içerir. ${ }^{3}$ Hastada klinik laküner sendromlardan birisi olmalıdır ve serebral kortikal disfonksiyon bulunmamalıdır. Diabetes mellitus veya hipertansiyon hikayesi tanıy destekler. Hastada ayrıca normal bir BT/MRG görüntülemesi veya çapı $1,5 \mathrm{~cm}$ 'den küçük beyin sapı veya subkortikal hemisferik lezyon bulunmalıdır. Potansiyel bir kardiyak emboli kaynağı ve ekstrakraniyal büyük arterlerin değerlendirmesinde ipsilateral bir arterde $\% 50$ 'den fazla stenoz bulunmamalıdır. ${ }^{3}$

Bilinen bir başka sebepten kaynaklanan akut inme: Bu kategori, non-aterosklerotik vaskülopati, hiperkoagülabilite veya hematolojik bozukluklar gibi nadir görülen inme sebeplerini içerir. $\mathrm{Bu}$ kategorideki hastaların klinik ve BT/MRG değerlendirmesinde, boyut ve konumdan bağımsız akut iskemik inme bulguları olmalıdır. Kan testleri ve arteriyografi gibi tanısal testler, bu sebeplerden birini ortaya koymalıdır. Kardiyak emboli ve büyük arter aterosklerozu, diğer çalışmalar ile dışlanmalıdır.

Sebebi bilinmeyen inme: Bazl durumlarda, inmeye neden olan sebep güvenilir bir şekilde bulunamaz. Bir kısım hastada, geniş çaplı incelemeye rağmen bir etiyoloji saptanamaz; bazılarında ise inceleme daha yüzeyseldir ve sebep bulunamaz. Bu kategori, aynı zamanda birden fazla potansiyel sebebin bulunduğu ve hekimin tam

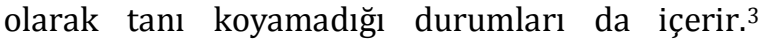

TOAST Sınıflamasına göre iskemik inme alt tiplerinin özellikleri ${ }^{3}$

\begin{tabular}{|c|c|c|c|c|}
\hline \multirow[b]{2}{*}{ Özellikler } & \multicolumn{4}{|l|}{ Alt tip } \\
\hline & $\begin{array}{l}\text { Büyük arter } \\
\text { aterosklerozu }\end{array}$ & $\begin{array}{l}\text { Kardiyak } \\
\text { emboli }\end{array}$ & $\begin{array}{l}\text { Küçük arter } \\
\text { oklüzyonu }\end{array}$ & $\begin{array}{l}\text { Diğer } \\
\text { sebepler }\end{array}$ \\
\hline \multicolumn{5}{|l|}{ Klinik } \\
\hline Kortikal veya serebellar disfonksiyon & + & + & - & $+/-$ \\
\hline Laküner sendrom & - & - & + & $+/-$ \\
\hline \multicolumn{5}{|l|}{ Görüntüleme } \\
\hline $\begin{array}{l}>1,5 \mathrm{~cm} \text { kortikal, serebellar, subkortikal } \\
\text { veya beyin sapı infarktı }\end{array}$ & + & + & - & $+/-$ \\
\hline $\begin{array}{l}<1,5 \mathrm{~cm} \text { subkortikal veya beyin sapı } \\
\text { infarktı }\end{array}$ & - & - & $+/-$ & $+/-$ \\
\hline \multicolumn{5}{|l|}{ Testler } \\
\hline Ekstrakraniyal internal karotis stenozu & + & - & - & - \\
\hline Kardiyak emboli kaynağ & - & + & - & - \\
\hline Testlerde diğer anomali & - & - & - & + \\
\hline
\end{tabular}

\section{KAYNAKLAR}

1. Sacco RL, Kasner SE, Broderick JP, Caplan LR, Connors JJ, Culebras A, Elkind MS, et al. An updated definition of stroke for the 21st century: a statement for healthcare professionals from the American Heart Association/American Stroke Association. Stroke. 2013 Jul; 44(7): 2064-89.

2. Jauch EC, Saver JL, Adams HP Jr, Bruno A, Connors JJ, Demaerschalk BM, et al. Guidelines for the early management of patients with acute ischemic stroke: a guideline for healthcare professionals from the American Heart Association/American Stroke Association. Stroke. 2013 Mar; 44(3): 870-947.
3. Adams HP Jr, Bendixen BH, Kappelle LJ, Biller J, Love BB, Gordon DL, Marsh EE 3rd. Classification of subtype of acute ischemic stroke. Definitions for use in a multicenter clinical trial. TOAST. Trial of Org 10172 in Acute Stroke Treatment. Stroke. 1993 Jan; 24(1): 35-41.

4. Chen PH, Gao S, Wang YJ, Xu AD, Li YS, Wang D. Classifying Ischemic Stroke, from TOAST to CISS. CNS Neurosci Ther. 2012 Jun; 18(6): 452-6.

5. Ihle-Hansen H, Thommessen B, Wyller TB, Engedal K, Fure B. Risk factors for and incidence of subtypes of ischemic stroke. Funct Neurol. 2012 Jan-Mar; 27(1): 35-40. 